\title{
KANUNISASI FIKIH JINAYAT KONTEMPORER Studi Materi Muatan Qānūn Jināyat Aceh dan Brunei Darussalam
}

\author{
Samsudin Aziz \\ IAIN Syekh Nurjati Cirebon \\ e-mail: samsudincrb@yahoo.co.id
}

\begin{abstract}
This article will view specifically codification of Islamic Criminal Law in 'Muslim community, such as Brunei Darussalam, a country based on Islamic principles, and Aceh is a part of Indonesian territory administratively, granted special autonomy to implement Islamic Sharia. Despite having different qualities, -as a country and a province- both have in common as a political power which apply Islamic Criminal Law. Refer to both qānūn jināyat in Brunei and Aceh, the author'll explain the substance of the criminal law in both area, while also reinforces the implementation of Islamic Criminal Law in the framework of a modern state. The article concludes that basically the application of Islamic Sharia, particularly the Islamic Criminal Law, is closely related to the situation and socio-political conditions of a community or country. The differences of political system, for example, has contributed to the difference in the output of product or policy made by a particular country or territory. On the other hand, Brunei and the Aceh case show that there has been adjustment Islamic Criminal Law specifically set forth in the books of fiqh (as illustration of the Qur'an and Sunnah) with the needs of the community itself.
\end{abstract}

[]

Artikel ini secara spesifik memotret kodifikasi Hukum Pidana Islam di komunitas Muslim, yaitu Brunei Darussalam yang merupakan negara dengan asas Islam dan Aceh yang secara administratif masuk ke wilayah Indonesia namun diberikan otonomi khusus untuk menerapkan syariat Islam. Meskipun memiliki kualitas yang berbeda, -sebagai sebuah negara dan sebuah provinsi- keduanya memiliki kesamaan sebagai sebuah kekuasaan politik yang menerapkan Hukum Pidana Islam. Dengan mengacu pada dua qānūn jïnāyat di Brunei dan Aceh tersebut, penulis menjelaskan substansi hukum pidana di kedua wilayah ini, sembari juga mempertegas pelaksanaan Hukum Pidana Islam dalam kerangka negara modern. Artikel ini berkesimpulan bahwa pada dasarnya penerapan Syariat Islam, terutama Hukum Pidana Islam, sangat terkait erat dengan situasi dan kondisi sosio-politik sebuah komunitas atau negara. Sistem politik yang berbeda, misalnya, telah memberikan kontribusi pada perbedaan produk atau keluaran dari kebijakan yang dibuat oleh negara atau wilayah kekuasaan tertentu. Di sisi yang lain, kasus Brunei dan Aceh menunjukkan bahwa telah terjadi penyesuaian-penyesuaian Hukum Pidana Islam secara spesifik yang termaktub dalam kitab-kitab fikih (sebagai gambaran dari al-Qur'an dan Sunnah) dengan kebutuhan-kebutuhan masyarakat itu sendiri.

Keywords: kanun, fiqh jināyah, ḥudūd,jarīmah, pidana Islam

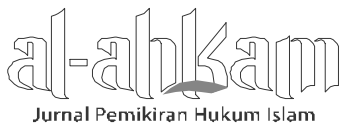




\section{Pendahuluan}

Salah satu aspek hukum Islam yang paling banyak tergantikan oleh hukum modern di masa kolonialisasi adalah hukum pidana, dibandingkan dengan aspek hukum Islam yang lain, seperti hukum keluarga atau bidang (fikih) muamalah. Hampir sebagian besar negara muslim yang mengalami masa kolonialisasi Barat di abad ke-17 sampai ke-20 menerapkan hukum pidana negara induknya, seperti halnya Indonesia yang menggunakan hukum pidana yang berasal dari Belanda dan termaktub di dalam Kitab Undang-Undang Hukum Pidana. Hingga saat ini, bahkan hukum pidana yang digunakan oleh Indonesia adalah hukum pidana warisan kolonial Belanda, dengan hanya sedikit modifikasi dan perubahan.

Kasus serupa juga terjadi di Brunei Darussalam, ketika Inggris masuk ke negara ini dan Kesultanan Brunei bersedia untuk berada di bawah protektorat Inggris. Dalam praktiknya, Inggris hanya mengizinkan Brunei untuk menerapkan hukum keluarga Islam, sementara hukum pidana yang telah ada sejak masa kesultanan digantikan dengan pidana Barat. Nampaknya, hal ini telah menjadi corak yang jamak di komunitas Islam, dan dengan ini pula kemudian penerapan hukum pidana Islam justru sangat jarang ada di negara-negara yang berpenduduk Muslim di masa-masa kolonialisasi.

Menyadur Daniel E. Price, Arskal Salim dan Azyumardi Azra mengemukakan tentang elemen-elemen penerapan Syariat Islam di komunitas atau negara-negara Muslim. Hal ini dapat dirumuskan dalam lima hal, yaitu: a) Hal-hal yang berkaitan dengan kedudukan personal (perdata), seperti perkawinan, perceraian, wakaf dan kewarisan; b) Pengaturan dalam hal ekonomi, seperti perbankan dan praktik bisnis/ usaha; c) Hal-hal yang terkait dengan praktik keagamaan, seperti pembatasan pada pakaian perempuan, mengkonsumsi alkohol, perjudian dan praktikpraktik yang dipandang tidak Islami; d) Pelaksanaan hukum pidana Islam, termasuk pula hukuman-hukumannya; e) Penggunaan Islam sebagai panduan dalam pemerintahan. ${ }^{1}$

Dari sini, memang hukum pidana menjadi aspek yang sangat jarang diterapkan, apabila dibandingkan dengan hukum keluarga atau hukum muamalah.

\footnotetext{
${ }^{1}$ Arskal Salim dan Azyumardi Azra, "Introduction: The State and Sharia in the Perspective of Indonesian Legal Politics", dalam Arskal Salim dan Azyumardi Azra, (ed.), Sharia and Politics in Modern Indonesia (Singapura: Institute of Southeast Asia Studies, 2003), h. 11.
} 
Setelah aspek muamalah lebih banyak diterapkan oleh masyarakat-masyarakat Muslim, sebagaimana banyak dilihat dari praktik perbankan dan sistem ekonomi Islam, dewasa ini, setidaknya melihat kasus Aceh dan Brunei Darussalam, muncul pula desakan dari umat Islam untuk menerapkan hukum pidana Islam. Adanya penetapan qānūn atau Undang-Undang Jinayat (di Brunei) ini memunculkan kembali praktik hukum pidana Islam yang selama ini telah ada sejak masa-masa Islam awal, walaupun pada praktiknya penerapan hukum pidana Islam ini masih sulit dipisahkan dari tradisi hukum dan administrasi kenegaraan modern yang disadur oleh negara-negara Muslim dari Barat di masa kolonial.

Artikel ini secara spesifik akan melihat bagaimana kodifikasi hukum pidana Islam di komunitas Muslim, yaitu Brunei Darussalam yang merupakan negara dengan asas Islam dan Aceh yang secara administratif masuk ke wilayah Indonesia namun diberikan otonomi khusus untuk menerapkan syariat Islam. Dengan mengacu pada dua qānūn jināyāt di Brunei dan Aceh tersebut, penulis akan menjelaskan tentang substansi hukum pidana di kedua wilayah ini, sembari juga mempertegas pelaksanaan hukum pidana Islam dalam kerangka negara modern sekarang ini.

\section{Kanunisasi dan Politik Hukum Islam Kontemporer Syariat Islam di Brunei Darussalam}

Sebelum datangnya Inggris di Brunei Darussalam dan menjadikan Brunei di bawah koloninya, Brunei yang memiliki sistem kesulatanan ini telah memiliki aturan tentang hukum Islam, yaitu berbentuk Hukum Kanun pada abad ke-15 dan 16 Masehi. $^{2}$ Pada masa Sultan Saiful Rijal, pengadilan bagi para pelanggar hukum telah diputuskan berdasarkan Hukum Kanun dan Resan, yang mengandung banyak unsur hukum Islam berdasarkan pada al-Qur'an dan sunnah. Masa pemerintahan Sultan Muhammad Hasan (1605-1619 M) kemudian menjadi titik awal terwujudnya Hukum Kanun Brunei, yang di antaranya disebabkan oleh hubungan kekeluargaan antara Brunei dan Pahang. Akibat kedekatan ini, Sultan Hasan menyalin undang-undang yang berlaku di Pahang - yang menyadur UU di Malaka- untuk diterapkan di Brunei. ${ }^{3}$

${ }^{2}$ Hal ini menurut catatan Antonio Pigafettayang datang ke Brunei pada tahun 1521.

3 Pengiran Dato Seri Setia Dr. Haji Mohammad bin Pangiran Haji Abd. Rahman, "Kemasukan Islam ke Brunei Darussalam dan Undang-undangnya", dalam Dato Seri Setia Haji Metussin bin Haji Baki, ed., Sejarah Penubuhan Mahkamah Syariah Negara Brunei Darussalam. (Brunei Darussalam: Jabatan Kehakiman Negara Brunei Darussalam, 2005), h. 29.

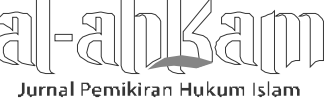


Hukum Kanun Brunei ini berisi 47 pasal dan diperkirakan 29 pasal di antaranya diadiopsi dari unsur-unsur ajaran Islam. Kanun ini meliputi bidang yang luas, termasuk di dalamnya adalah hukum pidana (hudūd, qișās dan ta'zīr), undangundang muamalah, hukum keluarga (pernikahan, perceraian dan fasakh), yang hampir semuanya berdasarkan pada hukum Syariat. ${ }^{4}$ Undang-undang ini kemudian disempurnakan pada masa Sultan Jalilul Akbar (1619-1652 M).

Ketika Inggris masuk ke wilayah Brunei dan lebih lagi ketika Brunei memutuskan diri untuk berada di bawah protektorat Inggris, pengaruh Inggris dalam permasalahan hukum di Brunei semakin menguat. Pada tahun 1898, sebuah Undangundang Hukum Pidana diterapkan di Brunei oleh Inggris, karena perjanjian antara Brunei dan Inggris menegaskan beberapa hal terkait dengan pengaturan hukum dan diserahkan sepenuhnya kepada Inggris. Di antara perjanjian tersebut adalah dalam bidang kekuasaan sipil dan hukum pidana terutama bagi kasus-kasus yang terjadi pada warga negara Inggris dan bidang kasus yang melibatkan warga negara Brunei apabila warga tersebut bertindak sebagai penuntut atau pendakwa. ${ }^{6}$

Kekuasaan Inggris terhadap hukum Brunei semakin menguat pasca Inggris membentuk Residennya di Brunei pada awal abad ke-20, sementara Kerajaan Brunei merasa bahwa hukum Islam dan adat setempat justru tidak mendapatkan tempat dalam kehidupan dan perundang-undangan Brunei. Sultan Brunei kemudian menuntut kepada perwakilan Inggris di Brunei agar kasus-kasus yang berkaitan dengan agama Islam diadili oleh hakim-hakim setempat dan meminta agar adat-adat dan undang-undang setempat tidak dirombak, dipindahkan ataupun dilanggar selamanya. Dari dua tuntutan ini, hanya permintaan pertama yang dikabulkan, terutama dalam penyelesaian sengketa-sengketa perdata, sementara dalam urusan pidana harus tetap merujuk kepada hukum Inggris. ${ }^{7}$

\footnotetext{
${ }^{4}$ Ahmad Abdussalam Abdur Rahman, "Brunei Darussalam Negara Zikir: Hasrat Sultan Hasanah Bolkiah", Artikel dipresentasikan dalam Annual Conference Islamic Studies (ACIS) ke-10, Banjarmasin, 1 - 4 November 2010, h. 70.

${ }^{5}$ Acep Zoni Saeful Mubarok, "Hukum Keluarga Islam di Brunei Darussalam”, dalam Atho' Mudzhar dan Khoiruddin Nasution, ed., Hukum Keluarga di Dunia Islam Modern: Studi Perbandingan dan Keberanjakan UU Modern dari Kitab-kitab Fikih (Ciputat: Ciputat Press, 2003), h. 178.

6Taher Mahmood, Personal Law in Islamic Countries (New Delhi: Academy of Law and Religion, 1987), h. 197-198; lihat pula, Acep Zoni Saeful Mubarok, Hukum Keluarga Islam di Brunei Darussalam, h. 179.
}

${ }^{7}$ Acep Zoni Saeful Mubarok, “Hukum Keluarga Islam di Brunei Darussalam”, h. 179.

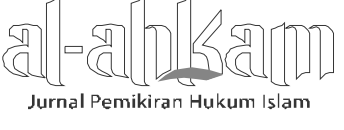


Memasuki paroh kedua abad ke-20, upaya untuk menerapkan Syariat Islam di Brunei semakin menguat. Pada masa pemerintahan Sultan Haji Omar Ali Saifuddien III (1950-1967) tercatat sejumlah kemajuan dalam bidang ajaran Islam, seperti mengirimkan anak-anak Brunei ke Sekolah Arab al-Junid di Singapura, membentuk Jabatan Hal Ehwal Agama pada tahun 1954, mengangkat Pegawai Ugama dari Kerajaan Negeri Johor pada 1955, mendirikan sekolah-sekolah agama pada 1956 dan tahun 1959 Sultan Haji Omar menjadikan agama Islam sebagai agama resmi negara. Sultan Omar pula yang mengangkat mufti kerajaan pertama Negara Brunei Darussalam pada $1962 .{ }^{8}$ Kebijakan-kebijakan ini kemudian terus dilanjutkan pada masa anaknya, yaitu Sultan Hasanah Bolkiah, yang di antaranya adalah menjadikan Brunei sebagai negara zikir dan menerapkan syariat Islam secara utuh.

\section{Sekilas tentang Penerapan Syariat Islam di Aceh}

Terdapat kecenderungan berbeda dalam kasus Aceh dibandingkan dengan wilayah lain di Indonesia. Hemat penulis hal ini terkait erat dengan politik hukum Belanda pada masa itu dan tak terlepas dari peranan besar Snouck Hugronje. Sejalan dengan organisasi pemerintahan Belanda di Nusantara sejak tahun 1881, telah diadakan pengadilan Landraad untuk penduduk non-pribumi di Aceh, ${ }^{9}$ namun bagi penduduk Aceh ditetapkan pengadilan Musapat dan Districtgerecht yang mendasarkan hukum materiilnya pada hukum adat setempat, sebagaimana ditegaskan di dalam Staatblad 1904 No. 473 dan Zelfbestuursregelen 1919, serta Musapat Ordonantie Staatblad 1916 No. 432. Dalam hal ini, pengadilan Musapat dan Districtgerecht memeriksa perkara pidana dan perdata di mana pribumi terlibat di dalamnya. Pengadilan Agama sendiri termasuk dalam sistem pengadilan Musapat ini, namun pengadilan agama tidak pernah menerapkan hukum pidana dan hanya terbatas pada keluarga. ${ }^{10}$

Sisi yang lain, terdapat ketentuan lain dalam penerapan hukum pidana adat di Aceh tersebut dan menjadi catatan dalam penerapannya, di antaranya adalah: Pertama, hukum pidana adat diperlakukan sepanjang tdak bertentangan dengan

\footnotetext{
${ }^{8}$ Ahmad Abdussalam Abdur Rahman, "Brunei Darussalam Negara Zikir: Hasrat Sultan Hasanah Bolkiah", h. 72-73.

9 Ditetapkan melalui Aceh Reglement, Staatblad 1881 No. 82.

${ }^{10}$ Lembaga Pembinaan Hukum Nasional (LPHN), Pengaruh Agama Islam terhadap Hukum Pidana, (Hasil Penelitian dalam Rangka Kerjasama LPHN dan Fakultas Hukum dan Pengetahuan Masyarakat Universitas Syah Kuala Darussalam, Banda Aceh, Tahun 1972), h. 17.
}

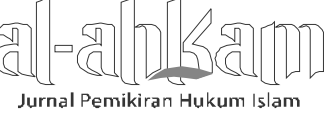


ketentuan-ketentuan yang tersebut di dalam perundang-undangan tertentu. Kedua, banyak ketentuan nasional yang disebutkan di dalam KUHP diterapkan kepada orang-orang pribumi. Ketiga, banyak juga ordonantie diperlakukan kepada orangorang bumi putera Aceh. Keempat, pengaruh Ketua/penasihat sidang Musapat tidak dapat diabaikan terhadap perkembangan hukum pidana adat, sehingga perkembangan seperti ini menghilangkan kesadaran ke arah kodifikasi hukum pidana adat itu sendiri. Kelima, sehubungan dengan perkembangan hukum adat ini, maka banyak keputusan-keputusan pidana dari Musapat didasarkan kepada normanorma yang disebut sebagai KUHP, sambil menunjuk pada pasal-pasalnya juga, seperti pencurian, penyaniayaan, penggelapan, pembunuhan, perzinaan, dan sebagainya, termasuk pula jenis dan besaran hukuman yang ditetapkan oleh pengadilan adat, walaupun terhadap tindak pidana ini masih disesuaikan dengan hukum Adat dan masih pula dimungkinkan penerapan hukum badan yang melebihi ketentuan KUHP. Keenam, banding atau eksaminasi putusan dilakukan oleh Gubernur atau Kepala Daerah yang pada umumnya memiliki pandangan hidup/ kesadaran hukum dan politik peradilan menurut prinsip-prinsip dunia Barat dan ditambah lagi dengan pandangan dalam politik peradilan tanah jajahan. Ketujuh, keputusan-keputusan Musapat tidak banyak yang dipublikasikan, hingga banyak yang terlepas dari sorotan para ahli hukum. ${ }^{11}$

Praktik hukum pidana adat yang demikian, pada batas-batas tertentu, dicatat telah menimbulkan beberapa implikasi pada penerapan hukum dan pembangunan sosial kemasyarakatan di Aceh, yang tergambar pada beberapa hal berikut: 1) Norma-norma adatrechtsdelict menjadi semakin kuat; 2) Kesadaran hukum bagi rakyat semakin menjurus kepada norma-norma di dalam KUHP; 3) Rakyat Aceh semakin merasa asing terhadap hukum adatnya, di dalam praktik tidak diberi kesempatan untuk berkembang secara wajar; 4) Para Kepala Adat pun menjadi berkurang minatnya untuk mengembangkan hukum pidana adat dan dalam batas tertentu tidak begitu kuat menahan anasir-anasir dari luar yang kadang bertentangan dengan ajaran Islam; 5) Ulama pun, sebagai akibat dari struktur kolonial bestuur, tidak memberikan partisipasi dalam perkembangan hukum pidana adat, karena mereka hanya bersikap stationnair dan tidak mau mengetahui perlunya "vermachtschappelijking" dari hukum Islam. ${ }^{12}$

\footnotetext{
11Lembaga Pembinaan Hukum Nasional (LPHN), Pengaruh Agama Islam terhadap Hukum Pidana, h. 17-18.

${ }^{12}$ Ibid., h. 19.

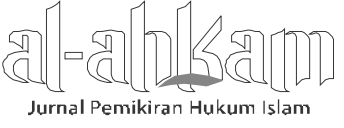


Jika ditelusuri lebih jauh tentang sejarah Aceh akan nampak bahwa dalam pandangan orang-orang Aceh, Hukum Syariat dan Hukum Adat tidak dapat dipisahkan. Adat dan agama telah menjadi dua unsur yang dominan dan mengendalikan gerak hidup rakyat Aceh di masa lampau. ${ }^{13}$ Hal ini, menurut Taufik Abdullah, setidaknya ada empat tonggak sejarah penting yang membentuk kesadaran masyarakat Aceh dan kecenderungan kulturalnya ini, yaitu: 1) proses Islamisasi; 2) jaman keemasan Sultan Iskandar Muda; 3) Perang melawan Belanda, 1873-1912; dan 4) Revolusi National, 1945-1949. ${ }^{14}$

Dalam proses Islamisasi, tidak dapat dipungkiri bahwa Aceh menjadi salah satu wilayah yang pertama-tama menganut Islam dan berkenalan dengan agama ini, yang kemudian mendirikan Kerajaan Pasai yang bercorak Islam. Di masa Sultan Iskandar Muda, Syariat Islam diterapkan secara sungguh-sungguh dan melandasi kehidupan rakyat Aceh, sehingga dikenal ungkapan: "adat bak Po Teumeureuhom, Hukom bak Teungku Syiah Kuala", yang menunjukkan Sultan Iskandar Muda dan Teungku Syiah Kuala (ulama) sebagai kepaduan antara adat (praktek hidup) dan hukum (syariat). Di masa penjajahan Belanda, sekali lagi memperlihatkan Islam merasuk dalam kehidupan rakyat Aceh secara keseluruhan, karena perang selama 40 tahun ini merupakan perang paling lama dan paling merugikan Belanda. Pada periode inilah terkenal Hikayat Perang Sabil yang membuat orang Aceh rela mati syahid untuk mengusir Belanda.

Periode Revolusi Nasional dan penggabungan wilayah nusantara di bawah naungan NKRI menegaskan keberhasilan rakyat Aceh mengatasi sentimen "keAceh-an" dan menjadi pendukung paling hebat berdirinya Republik Indonesia. Teungku Daud Beureueh pada tahun 1949 menyatakan:

"Kesetiaan rakyat Aceh terhadap Pemerintah RI bukan dibuat-buat serta diada-adakan, tetapi kesetiaan yang tulus dan iklas yang keluar dari lubuk hati nurani dengan perhitungan dan perkiraan yang pasti”."

Memasuki era reformasi dan perdamaian Helsinki, Aceh kemudian mendapatkan status otonominya untuk menerapkan Syariat Islam, termasuk hukum pidana,

${ }^{13}$ Lihat lebih lanjut tentang sejarah Aceh dalam T. Iskandar, Aceh dalam Lintasan Sejarah: Suatu Tinjauan Kebudayaan, (Prasaran pada Seminar Kebudayaan dalam rangka PKA II dan Dies Natalis XI Universitas Syiah Kuala, 21-25 Agustus 1972 di Banda Aceh).

${ }^{14}$ Marsen S. Naga, "Hukum Jinayat di Aceh", dalam Aceh Kita, 10 Desember 2009, diakses dari http://www.acehkita.com/2009/12/hukum-jinayah-di-aceh/

15 Marsen S. Naga, "Hukum Jinayat di Aceh", dalam Aceh Kita.

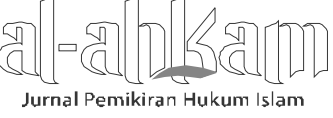


yang membedakannya dengan hukum di wilayah lain. Penerapan Syariat Islam ini secara utuh ditegaskan di dalam UU No. 44 Tahun 1999 tentang Keistimewaan Daerah Istimewa Aceh dan UU No. 18 Tahun 2001 tentang Otonomi Khusus bagi Provinsi Daerah Istimewa Aceh yang merevisi UU ini. Kedua UU ini kemudian menjadi legitimasi bagi penerapan Syariat Islam di Aceh sebagai hukum materil yang mengembangkan dan mengatur pendidikan sesuai dengan ajaran Islam, mengembangkan dan menyelenggarakan kehidupan adat, dan mengembangkan peran serta kedudukan ulama dalam penerapan kebijakan daerah. Dengan kewenangan ini, sekitar 13 Qānūn Syariat Islam telah ditetapkan di Aceh, termasuk Qānūn Jināyat.

Sejak dinyatakan sebagai wilayah syariat, penegakan Qānūn Jināyat di Aceh mengalami fluktuasi dan dinamika yang sangat beragam. Pro dan kontra penegakannya tidak dapat dihindari sehingga pada akhirnya memunculkan kelompokkelompok yang mendukung, tidak mendukung, dan kelompok yang tidak peduli dengan syariat Islam di kalangan masyarakat Aceh. Syariat Islam juga diterapkan dengan pelbagai level, mulai dari tingkat yang terendah sampai tingkat provinsi, untuk sejumlah delik pidana, seperti pelaku khalwat atau mesum, peminum khamar, dan judi.16 Pada tahun 2003, DPR Aceh mengesahkan tiga Qānūn Syariat sekaligus, yaitu Qānūn No. 12, 13 dan 14, masing-masing tentang khamar, maysīr (judi) dan khalwat.

Setelah hukum pidana diterapkan di Aceh, dengan sejumlah qānūn jināyāt yang terpisah, muncul inisiasi dari DPR Aceh untuk mengkodifikasikan aturan-aturan pidana Islam tersebut dalam satu Qānūn yang kemudian baru disahkan pada bulan September tahun 2014, bersamaan dengan ke-6 qānūn yang lain. Qānūn Hukum Jinayat merupakan qānūn yang lebih banyak mendapatkan perhatian, baik di Aceh, di tingkat nasional, bahkan dari komunitas internasional. Qānūn Jināyat ini merupakan qānūn yang diusulkan oleh Pemerintah Aceh sebagai perwujudan dari UU No. 11 Tahun 2006 tentang Pemerintahan Aceh. Adanya qānūn tersebut, setiap pelanggaran pidana yang dicantumkan di dalam Qānūn akan diterapkan kepada seluruh warga Aceh. Sementara bagi non-Muslim di Aceh diberikan keleluasaan untuk memilih hukum pidana Islam sebagaimana di dalam Qānūn atau merujuk pada hukum nasional. ${ }^{17}$

\footnotetext{
16Mahdi, “Sistem Hukum Penegakan Qanun Jinayat di Aceh”, dalam Media Syariah, Vol. XIII, No. 2, Juli - Desember 2011, h. 187.

17“Hukum Pidana Islam, DPR Aceh Sahkan Qanun Hukum Jinayat", Kompas, 27 September 2014, diakses dari http://regional.kompas.com/read/2014/09/27/11445201/Hukum Pidana Islam, DPR Aceh Sahkan Qanun Hukum Jinayat.
} 


\section{Hukum Pidana Islam dan Perkembangan Negara Modern}

Perspektif hukum Islam, jarimah diartikan sebagai segala sesuatu yang dilarang oleh syariat dan ditetapkan hukumannya melalui hudūd atau ta'zìr oleh Allah SWT. Larangan-larangan tersebut adalah melaksanakan apa yang dilarang oleh-Nya atau meninggalkan apa yang diperintahkannya, yang juga disifati dengan syariat. $^{18}$ Bertujuan untuk menjaga kemaslahatan kehidupan masyarakat dan memelihara berlangsungnya sebuah masyarakat, Islam menetapkan sejumlah perbuatan yang termasuk sebagai jarīmah dan diberikan sanksi atas perbuatan itu.

Pada dasarnya, yang dimaksud dengan jarimah ini adalah mencakup maksiatmaksiat yang diancam hukumannya di dunia ataupun di akhirat. Hanya saja, karena sejumlah pembahasan hukum pidana ini dikaitkan dengan kekuasaan pemerintahan, jināyāt seringkali lebih ditekankan pada tindak kejahatan dan hukuman di dunia, yaitu kemaksiatan yang hukumannya diterapkan oleh lembaga peradilan. Al-Mawardi mengatakan, jarimah dimaksudkan sebagai laranganlarangan yang diganjar hukumannya dengan hadd atau ta'zīr.

Hudūd atau hadd merupakan hukuman yang jelas ukuran dan ketentuannya, termasuk pula di dalamnya adalah qișās dan denda yang telah ditetapkan oleh syariat di dalam al-Qur'an dan sunnah. Sementara ta'zīr adalah hukumanhukuman yang diserahkan sepenuhnya kepada para pemimpin atau hakim dengan pertimbangan dapat mencegah terjadinya kerusakan di dunia dan terjadinya kejahatan, yang dengannya pula sebuah tatanan masyarakat itu ditegakkan. ${ }^{19}$ Dari sini, dapat diketahui bahwa dalam hukum Islam, terdapat sejumlah tindak pidana yang ditetapkan hukumannya secara jelas oleh al-Qur'an atau sunnah, namun ada tindak pidana yang tidak disebutkan hukumannya secara jelas, sehingga diperlukan peran serta para pemimpin atau hakim untuk menetapkannya.

Hukuman-hukuman yang termasuk dalam ḥudūd ini adalah: tindak pidana perzinaan, qadhaf atau menuduh orang lain berzina, meminum khamar, mencuri atau sariqah, perampokan atau qaț al-țāriq, murtad atau riddah, yang semuanya juga disbeut hudūd. Hudūd secara bahasa adalah batasan atau garis, yang dapat pula diartikan sebagai hukuman-hukuman yang tidak dapat dikurangi ataupun

${ }^{18} \mathrm{Abd}$ al-Qādir 'Awdah, al-Tashrī’ al-Jinā̄îal-Islāmī: Muqāranah bi '-Qanūn al-Waḍ̂̄î(Beirut: Dār alKutub al-'Arabī, tth.), juz I, h. 66.

${ }^{19}$ Abu Zahrah, al-Jarimah wa '1-Uqūbah fi 'I-Fiqh al-Islāmī (Kairo: Dar al-Fikr Al-Arabi, 1998), h. 20.

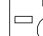

Jurnal Pemikiran Hukum Islam 
distambahkan ukurannya, sebagaimana telah ditetapkan oleh Allah SWT. ${ }^{20}$ Selain hudūd, ada pula jarīmah yang juga ditetapkan oleh Allah SWT di dalam al-Qur'an atau sunnah, yaitu hukuman jarimah qișaș atau diyat (denda), yaitu hukuman yang ditetapkan untuk tindak pidana pembunuhan atau penghilangan nyawa manusia. Ulama membedakan jarīmah ini menjadi dua, yaitu qișaș șurah wa ma'nā dan qișāṣ ma'nā saja. Untuk yang pertama dimaksudkan sebagai hukuman yang ditetapkan kepada pelaku kejahatan sebagaimana yang ditegaskan di dalam al-Qur'an dan sunnah, sementara qișāṣ al-ma'nā merupakan hukuman yang berbentuk diyat atau denda sebagai ganti dari hukuman qișāṣ. ${ }^{21}$

\section{Bentuk Jarimah dan Hukuman dalam Pidana Islam²}

\begin{tabular}{|c|c|c|}
\hline $\begin{array}{c}\text { Jarīmah } \\
\text { (Tindak Pidana) }\end{array}$ & ‘Uqubat (Hukuman) & Keterangan \\
\hline Zina & 100 kali cambukan & $\begin{array}{l}\text { QS. al-Nur: 2; QS. al-Anfal } \\
38\end{array}$ \\
\hline Qadhaf & 80 kali cambukan & QS. al-Nur: 4 \\
\hline Meminum khamar & 40 kali cambukan & $\begin{array}{l}\text { Ditetapkan berdasarkan } \\
\text { Sunnah fi'liyyah yang di- } \\
\text { lakuan oleh Rasulullah }\end{array}$ \\
\hline Pencurian & Potong tangan & QS. al-Ma'idah: 38 \\
\hline Hirabah (perampokan) & $\begin{array}{l}\text { Dibunuh; disalib; } \\
\text { dipotong tangan dan kaki }\end{array}$ & QS. al-Ma'idah: 33 - 34 . \\
\hline Murtad & Dibunuh & $\begin{array}{l}\text { Ditetapkan oleh Rasulul- } \\
\text { lah dalam Hadis. }\end{array}$ \\
\hline Pemberontakan & $\begin{array}{l}\text { Dibunuh, kecuali ada per- } \\
\text { damaian. }\end{array}$ & QS.al-Ḥujurat: 9 \\
\hline Pembunuhan & Qișaș atau diyat & QS. al-Baqarah: 178-179 \\
\hline
\end{tabular}

Hukum Islam sendiri, termasuk di dalamnya fikih jinayah, tumbuh dalam kehidupan masyarakat Muslim yang berbeda-beda, dengan aliran hukum yang juga sangat beragama. Walaupun kemudian, hanya empat mazhab besar yang 76.

\footnotetext{
${ }^{20} \mathrm{Abū}$ Zahrah, al-Uqūbah; al-Jarīmah wa '-'Uqūbah fi al-Islām (Kairo: Dār al-Fikr al-'Arabī, t.th.), h.

21 Ibid., h. 78.

22 Ibid., h. 137-138.
}

182 || Volume 24, Nomor 2, Oktober 2014

Jurnal Pemikiran Hukum Islam 
tumbuh hingga sekarang dan digunakan di belahan dunia Muslim. Dalam penerapannya tersebut, para ahli hukum fikih menerima keragaman interpretasi dan menyadari adanya kesalahan dalam setiap pendapat yang mereka keluarkan, sembari tetap mencari titik temu (konsensus) sejara ijma' ${ }^{23}$

Seiring dengan perjalanan waktu, dengan masuknya pemerintahan kolonial di negara-negara Muslim, terjadi pembatasan-pembatasan penerapan Syariat Islam di pengadilan, yang secara spesifik hanya terfokus pada hukum keluarga Islam (aḥwāl al-shakhșiyyah). Sementara itu, hukum pidana dan hukum sipil digantikan dengan hukum kolonial, baik yang berasal dari negara-negara bercorak common law seperti Inggris ataupun Eropa Kontinental seperti Belanda dan Perancis. Masamasa ini menjadi titik awal perpindahan hukum Islam kepada model Eropa, sebagaimana pertama kali secara simbolik diterapkan oleh pemerintahan Turki Utsmani pada tahun 1924 dengan menghapuskan sistem khalifah. ${ }^{24}$

Ketika negara-negara Muslim ini merdeka dan memiliki otonomi untuk menerapkan sistem hukumnya sendiri, sejumlah negara mengembalikan penerapan hukum pidana Islam tersebut dalam kehidupan bernegara, namun sejumlah yang lain tetap melanjutkan sistem hukum warisan kolonial. Secara sosiologis, keberadaan Syariat Islam tetap menjadi harapan komunitas Muslim dengan menjadikannya sebagai sumber hukum nasional, sebagaimana penelitian yang diungkap oleh Gallup World Poll. Penelitian tersebut menyebutkan sebanyak 79\% umat Islam di 10 negara Muslim yang menjadi sasaran penelitian menghendaki Syariat Islam dijadikan sumber hukum. ${ }^{25}$

Kecuali yang terjadi di Arab Saudi, negara-negara Muslim kemudian menerapkan kembali hukum pidana Islam melalui proses ijtihad dan legislasi, karena secara faktual bidang hukum Islam ini telah dihilangkan oleh Kolonial. Di sisi lain, kecenderungan penerapan hukum pidana Islam ini mengarah pada "pencangkok-

\footnotetext{
${ }^{23}$ Abdullāhi Ahmed al-Naim, "Sharia in the Secular State: A Paradox of Sparation and Conflation", dalam Peri Bearman, dkk, ed., The Law Applied: Contextualizing the Islamic Sharia (London \& New York: IB Taurus, 2008), h. 329.

${ }^{24}$ Abdullāhi Ahmed al-Naim, "Sharia in the Secular State", h. 330.

${ }^{25}$ Secara garis besar, 10 negara yang diteliti terbagi menjadi dua, yaitu secara minoritas mendukung Syariat sebagai sumber hukum (yaitu Libanon, Turki, Indonesia, Iran, dan Maroko) dan warga Negara yang mayoritas mendukung Syariat sebagai sumber hukum, yaitu Mesir, Pakistan, Yordania, Bangladesh. Lihat, Tahir Wasti, The Application of Islamic Criminal Law in Pakistan: Sharia in Practice (Leiden and Boston: Brill, 2009), h. 1.
}

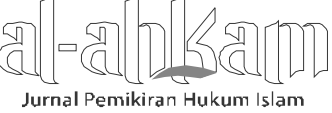


an" pada sistem hukum kolonial Barat sebagai warisan penjajahan, karena secara sistemik hukum Islam tidak cukup memadai untuk menerapkan seluruh komponen penerapan hukum pidana Islam yang baru dimunculkan kembali tersebut. Hal ini berimplikasi pada kenyataan, hukum pidana materil Barat yang telah menguasai sistem hukum negara-negara Muslim digantikan dengan hukum pidana Islam, walaupun prosedur penerapannya tetap menggunakan kerangka hukum Barat. Dalam istilah al-Muhairi, dikutip oleh Tahir Wasti, "Islamisasi hukum" yang diterapkan oleh negara-negara Muslim adalah praktik pencangkokan hukum Islam pada sistem hukum Barat yang telah mapan di negara-negara bekas jajahan ini. ${ }^{26}$

Kenyataan bahwa Negara-negara Muslim berada pada sistem nations-state, yang nota bene merupakan model yang diadopsi dari Barat, tidak bisa ditolak. Model ini meniscayakan adanya sentralisasi dan birokratisasi tatanan administrasi dan hukum sebuah Negara, yang dijalankan oleh staf administasi, dengan otoritas yang mengikat untuk semua teritorial wilayahnya, berdasarkan pada batas-batas wilayah yang tegas dan adanya keabsahan untuk menggunakan "kekuatan". ${ }^{27}$ Sistem demikian meniscayakan pula pengelolaan negara secara profesional dan akuntabel, dengan menegaskan prinsip-prinsip kehidupan bernegara dan berbangsa, tanpa mengindahkan latar belakang orang-orang yang berada di bawah kekuasaannya. Dalam hal ini pula kemudian ketegasan pembedaan agama dan negara, menurut sejumlah pandangan, menjadi penting, yaitu bagaimana negara tidak kemudian berpihak pada agama tertentu dan kemudian mendiskriminasikan kelompok agama-agama minoritas yang ada di wilayahnya. Di sisi lain, penerapan Syariat Islam oleh negara harus pula mendapatkan persetujuan dari setiap orang yang ada di wilayahnya, sehingga penerapan Syariat tersebut betul-betul berangkat dari keinginan dan kehendak dari setiap orang, bukan merupakan pemaksaan dari negara. $^{28}$

Kajian politik Islam, sejumlah intelektual Islam kemudian membedakan antara identitas politik pembangunan negara yang berdasarkan pada agama dan kewargaan. Menurut pandangan ini, dalam kehidupan modern dewasa ini, sebuah negara tidak lagi dibangun atas dasar identitas kelompok, seperti agama, namun

\footnotetext{
26Tahir Wasti, The Application of Islamic Criminal Law in Pakistan, h. 3.

27Lebih lanjut tentang karakteristik negara-bangsa ini, lihat, Abdullahi Ahmed An-Naim, Islam and the Secular State: Negotiating the Future of Shari'a (USA: Harvard University Press, 2008), h. 86-87.

${ }^{28}$ Abdullahi Ahmed al-Naim, Islam and the Secular State, h. 95.
}

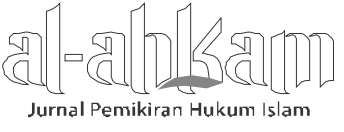


lebih pada keumuman identitas setiap orang untuk hidup di bawah naungan sebuah kedaulatan Negara. Konsekuensinya, setiap orang memiliki hak dan status yang sama, tanpa dibeda-bedakan, sehingga tatanan hukum yang mengarah pada pembedaan atau diskriminasi justru menjadi tidak relevan dalam kehidupan dan fakta sosial yang ada. Konsensus sebuah bangsa yang terdiri dari warga negara yang berbeda-beda harus diwujudkan secara setara melalui konstitusi dan landasan hukum bersama yang setara. ${ }^{29}$

Hal ini kemudian memunculkan polemik dalam kehidupan sosial dan politik umat Islam dalam kaitannya dengan komunitas yang ada di luarnya. Sebagaimana diungkap oleh Mashood Baderin dalam tulisannya, bahwa setidaknya Islam mendapatkan citra buruknya di mata Barat karena penerapan hukum pidana Islam seringkali tidak mengindahkan situasi politik, kemajuan zaman dan prinsipprinsip hak asasi manusia. Bahkan, pada ranah akademis, mengutip Strawson, Baderin mengungkap istilah 'problematika orientalis' (orientalist problematique) yang melaluinya hukum Islam ditampilkan dalam kesarjanaan Anglo-Amerika sebagai sistem hukum yang pada esensinya cacat, terutama dalam hubungannya dengan hukum internasional. ${ }^{30}$

Sementara di sisi yang lain, menurut Baderin, ada kendala penafsiran konservatif yang kaku terhadap syariat dan penerapan non-relatif atas yurisprudensi tradisional Islam pada beberapa aspek hubungan antar-manusia. Syariat Islam seringkali secara samar diajukan oleh sejumlah negara Muslim sebagai dalih atas catatan HAM mereka yang buruk tanpa memberikan penjelasan tuntas mengenai ketentuan hukum Islam dalam masalah yang bersangkutan, termasuk dalam hal penerapan hukum pidana. Hal ini mengarahkan komunitas Islam berada pada posisi defensif dan apologetik di hadapan tantangan-tantangan nyata kehidupan modern. ${ }^{31}$

Dengan demikian, penerapan hukum pidana Islam kemudian di satu sisi berada pada arus perkembangan tatanan kehidupan politik modern, namun di sisi yang lain secara substansial seringkali tidak cukup dapat menyesuaikan dengan

\footnotetext{
${ }^{29}$ Ahmad Sueadi, dkk., (ed.), Islam, Konstitusi, dan Hak Asasi Manusia (Jakarta: The Wahid Institute, 2009),h. 102.

30Mashood Baderin, Hukum Internasional Hak Asasi Manusia dan Hukum Islam (Jakarta: Komnas HAM, 2010), edisi terjemahan, h. 8.

31 Ibid, h. 8-10.

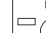

Jurnal Pemikiran Hukum Islam 
kebutuhan dan tuntutan sistem yang modern itu. Hal ini, nampaknya, menjadi kecenderungan penerapan hukum pidana Islam di negara-negara Muslim, sebagaimana pula yang terjadi di negara dan wilayah yang dibahas dalam artikel ini, yaitu di Brunei Darussalam dan Aceh.

\section{Hukum Pidana Islam Modern dalam Kajian Komparatif Aceh dan Brunei Darussalam}

Qānūn Jināyat Aceh dibagi menjadi sepuluh Bab, mengatur tentang aspekaspek yang berbeda terkait dengan hukum pidana Islam di Aceh. Bab-bab ini adalah: Ketentuan Umum (Bab I), Asas dan Ruang Lingkup (Bab II), Alasan Pembenar dan Pemaaf (Bab III), Jarimah dan 'Uqūbat (Bab IV), Perbarengan Perbuatan Jarimah (Bab V), Jarimah dan 'Uqūbat Bagi Anak (Bab VI), Ganti Kerugian dan Rehabilitasi (Bab VII), Ketentuan Lain-lain (Bab VIII), Ketentuan Peralihan (Bab IX) dan Ketentuan Penutup (Bab X). Pasal 2 Qānūn jināyat Aceh

Aceh memiliki sejumlah asas penerapannya, yang penyelenggarannya didasarkan pada asas-asas tersebut, yaitu keislaman, legalitas, keadilan dan keseimbangan, kemaslahatan, perlindungan hak asasi manusia, dan pembelajaran kepada masyarakat (tadabbur).

Selanjutnya, Qānūn jināyat Aceh juga mengatur ruang lingkup penerapannya, yang dijelaskan di dalam Pasal 3 Ayat (1). Pasal ini menegaskan bahwa Qānūn ini mengatur tiga hal terkait dengan Hukum Pidana Islam, yaitu: pelaku jarīmah, jarīmah, dan 'uqūbat. Jarimah di dalam Qānūn ini diartikan sebagai "perbuatan yang dilarang oleh Syariat Islam yang dalam Qānūn ini diancam dengan 'uqūbat hudud dan/atau ta'zir". Sementara 'uqūbat adalah "hukuman yang dapat dijatuhkan oleh hakim terhadap pelaku jarimah".32

Secara lebih spesifik, jarimmah atau perbuatan yang dilarang di dalam Qānūn ini terdiri dari 10 tindak pidana, sebagaimana dijelaskan lebih detil di dalam Pasal 1 Qānūn, yaitu: khamar, ${ }^{33}$ maysīr, ${ }^{34}$ khalwat, $^{35}$ ikhtilāt, ${ }^{36}$ zina, ${ }^{37}$ pelecehan seksual, ${ }^{38}$ pemerkosaan,39 qadhaf, liwāț,40 dan musāhaqah. ${ }^{41}$

\footnotetext{
32Pasal 1 butir 16 dan 17 Qānūn jināyat Aceh 2014.

${ }^{33}$ Khamar adalah minuman yang memabukkan dan/atau mengandung alkohol dengan kadar 2\% (dua persen) atau lebih.
}

186 || Volume 24, Nomor 2, Oktober 2014

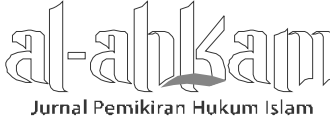


Sejumlah bentuk tindak pidana yang diatur di dalam Qānūn Aceh tersebut di atas, memperlihatkan perbedaan dengan fikih klasik dalam hal jināyāt. Demikian halnya dengan pengertian, hal ini menjadi sangat dapat diperdebatkan dan didiskusikan lebih lanjut sebagaimana yang akan penulis jelaskan pada bagian selanjutnya tulisan ini.

Qānūn jināyat Aceh juga mengatur tentang wilayah pemberlakuan (yurisdiksi) Qānūn, yang meliputi empat kelompok besar, yaitu: pertama, setiap orang beragama Islam yang melakukan jarīmah di Aceh. Kedua, setiap orang beragama bukan Islam yang melakukan jarimah di Aceh bersama-sama dengan orang Islam dan memilih serta menundukkan diri secara sukarela pada Hukum Jinayat. Ketiga, setiap orang beragama bukan Islam yang melakukan perbuatan jarimah di Aceh yang tidak diatur dalam Kitab Undang-Undang Hukum Pidana (KUHP) atau ketentuan pidana di luar KUHP, tetapi diatur dalam Qānūn ini; dan keempat, badan usaha yang menjalankan kegiatan usaha di Aceh. ${ }^{42}$

\footnotetext{
${ }^{34}$ Maysìr adalah perbuatan yang mengandung unsur taruhan dan/atau unsur untung-untungan yang dilakukan antara 2 (dua) pihak atau lebih, disertai kesepakatan bahwa pihak yang menang akan mendapat bayaran/keuntungan tertentu dari pihak yang kalah baik secara langsung atau tidak langsung.

${ }^{35}$ Khalwat adalah perbuatan berada pada tempat tertutup atau tersembunyi antara 2 (dua) orang yang berlainan jenis kelamin yang bukan mahram dan tanpa ikatan perkawinan dengan kerelaan kedua belah pihak.

36Ikhtilät adalah perbuatan bermesraan seperti bercumbu, bersentuh-sentuhan, berpelukan dan berciuman antara laki-laki dan perempuan yang bukan suami istri dengan kerelaan kedua belah pihak, baik pada tempat tertutup atau terbuka.

37Zina adalah persetubuhan antara seorang laki-laki dan seorang perempuan tanpa ikatan perkawinan dengan kerelaan kedua belah pihak.

38Pelecehan Seksual adalah perbuatan asusila atau perbuatan cabul yang sengaja dilakukan seseorang di depan umum atau terhadap orang lain sebagai korban baik laki-laki maupun perempuan tanpa kerelaan korban.
}

${ }^{39}$ Pemerkosaan adalah hubungan seksual terhadap faraj atau dubur orang lain sebagai korban dengan zakar pelaku atau benda lainnya yang digunakan pelaku atau terhadap faraj atau zakar korban dengan mulut pelaku atau terhadap mulut korban dengan zakar pelaku, dengan kekerasan atau paksaan atau ancaman terhadap korban

${ }^{40}$ Liwāț adalah perbuatan seorang laki-laki dengan cara memasukkan zakarnya kedalam dubur laki-laki yang lain dengan kerelaan kedua belah pihak.

${ }^{41}$ Musāhaqah adalah perbuatan dua orang wanita atau lebih dengan cara saling menggosokgosokkan anggota tubuh atau faraj untuk memperoleh rangsangan (kenikmatan) seksual dengan kerelaan kedua belah pihak. Lihat juga dalam pasal 3 ayat 2 Qānūn jināyat Aceh 2014.

42Pasal 5 Qānūn jināyat.

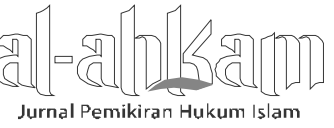


Selanjutnya, tulisan ini akan sedikit menguraikan tentang struktur hukum Kanun Jenayat ${ }^{43}$ Brunei Darussalam yang telah ditetapkan melalui Perintah Perkara No. 83 (3) melalui Warta Kerajaan Negara Brunei Darussalam pada 22 Oktober 2013. Secara garis besar, Kanun Jenayat Brunei dibagi menjadi lima bagian besar, yaitu: Permulaan (Bagian I), Kecualian 'Am/Umum (Bagian II), Shubaḥāt (Bagian III), Kesalahan-kesalahan (Bagian IV), dan uraian 'Am/Umum (Bagian V).

Bagian I tentang permulaan, mengatur tentang ketentuan umum terkait dengan Kanun Jenayat, seperti pengertian dan definisi, sasaran penerapan hukum Jenayat, kriteria penetapan keislaman seseorang dan pengecualian. Bagian II mengatur tentang pengecualian, meliputi 24 daftar tindakan-tindakan yang dikecualikan dan dianggap bukan sebagai tindakan pidana (jarimah) karena alasan-alasan tertentu, seperti tindakan hakim yang menjalankan hukum Syariat atau Mahkamah (Pasal 7 dan 8 Kanun), ketidaksengajaan (Pasal 10 Kanun), perbuatan oleh orang yang tidak sempurna akalnya (Pasal 14), dan perbuatan yang dilakukan oleh orang yang belum baligh atau anak kecil (Pasal 18). ${ }^{44}$

Bagian III shubhat- shubhat, mengatur tentang hal-hal yang termasuk ke dalam tindak pidana yang terkategori sebagai shubhat, yaitu tindakan-tindakan yang tidak secara murni dilakukan oleh seseorang dan di luar dari tindakan pidana yang ditetapkan di dalam Kanun, seperti orang yang menganjurkan orang lain untuk melakukan sebuah tindakan pidana.

Pada bagian IV, Kanun Jenayat Brunei baru menjelaskan tentang kesalahankesalahan yang dalam bahasa fikih atau Qānūn jināyat Aceh disebut dengan jarimah. Bagian jarīmah ini dibagi menjadi 4 bagian besar, yaitu: 1) Sariqah (pencurian), hirābah (perampokan), zina, zinā bi l-jabar (zina dengan pemaksaan), liwāt (homoseksual), qadhaf (menuduh orang berbuat zina tanpa ada saksi), meminum minuman yang memabukkan dan irtidād (keluar dari agama Islam); 2) Qatl (pembunuhan) dan kecederaan; 3) Menarik balik sumpah; dan 4) Kesalahankesalahan umum ('äm).

\footnotetext{
43Tulisan "Kanun Hukuman Jenayat" untuk menyebutkan hukum pidana Brunei Darussalam ini merujuk pada penamaan resmi yang dikeluarkan berdasarkan Perintah di bawah Perkara 83(3) tahun 2013.

${ }^{44}$ Lihat Pasal 6 sampai 36 Kanun Hukuman Jenayat Brunei Darussalam.
}

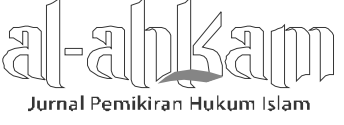


Dari struktur jarimah di atas, dapat diketahui bahwa Kanun Jenayat Brunei mengatur secara khusus tindak pidana yang termasuk dalam jarīmah qișās dan hudūd, baru kemudian mengatur tentang jarimah-jarimah yang tidak termasuk dalam keduanya. ${ }^{45}$ Sebagai tambahan dari hadd tersebut, Kanun memasukkan zina bi 'l-jabar dan liwāt ke dalam kategori zina. Dari sini pula tampak perbedaan struktur pengaturan dengan apa yang telah ditetapkan di Aceh, yang relatif lebih fleksibel dalam menyusun struktur jarīmah-nya.

\section{Perbandingan Hukuman Antara Qānūn j̈nāyat Aceh dan Kanun Jenayat Brunei Darussalam ${ }^{46}$}

\begin{tabular}{|c|c|c|}
\hline \multirow[t]{2}{*}{ Jarimah } & \multicolumn{2}{|c|}{ Hukuman } \\
\hline & Aceh & Brunei \\
\hline Sarīqah & Tidak ada & $\begin{array}{ll}\text { - } & \text { Dipotong pada sendi } \\
\text { pergelangan tangan kanan; } \\
\text { - } & \text { Dipotong kaki kiri sampai } \\
& \text { buku kaki. } \\
\text { - } & \text { Penjara maksimum } 15 \\
\text { tahun. }\end{array}$ \\
\hline Hirābah & Tidak ada & 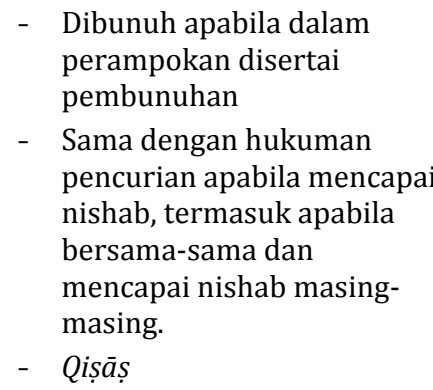 \\
\hline Khamar & 40 kali cambuk & $\begin{array}{l}40 \text { kali cambuk kesalahan } \\
\text { pertama, } 80 \text { kali cambuk } \\
\text { kesalahan kedua, } 80 \text { kali } \\
\text { cambuk dan penjara maksimal } \\
2 \text { tahun untuk kesalahan ketiga }\end{array}$ \\
\hline
\end{tabular}

${ }^{45}$ Di dalam Kanun Jenayat Brunei ini juga ditegaskan, bahwa yang dimaksud dengan hadd adalah hukuman atau siksaan yang telah ditetapkan al-Qur'an dan Sunnah Rasulullah SAW, bagi kesalahan sarīqah, hirābah, zina, qadhaf, meminuman yang memabukkan dan irtidād. Pasal 52 (1) Kanun Jenayat Brunei Darussalam.

46Dikelola oleh penulis dari kedua sumber hukum pidana Islam Brunei Darussalam dan Aceh

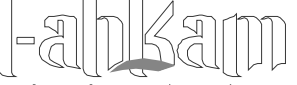




\begin{tabular}{|c|c|c|}
\hline Maysir & $\begin{array}{l}12 \text { kali cambuk/ } 120 \\
\text { gram emas murni/12 } \\
\text { bulan penjara }\end{array}$ & Tidak ada \\
\hline Khalwat & $\begin{array}{l}10 \text { kali cambuk/ } 100 \\
\text { gram emas/ } 10 \text { bulan } \\
\text { penjara }\end{array}$ & $\begin{array}{l}\text { Denda } 4000 \text { USD, penjara } \\
\text { maksimal } 1 \text { tahun, atau } \\
\text { keduanya (berlaku bagi Muslim } \\
\text { dan non-Muslim) }\end{array}$ \\
\hline Ikhtilāt & $\begin{array}{l}30 \text { kali cambuk/ denda } \\
450 \text { gram emas/ } 45 \\
\text { bulan }\end{array}$ & \\
\hline $\begin{array}{l}\text { Menuduh melakukan } \\
\text { ikhtilath }\end{array}$ & $\begin{array}{l}30 \text { kali cambuk/ } 300 \\
\text { gram emas / } 30 \text { bulan }\end{array}$ & \\
\hline Zina & 100 kali cambuk & $\begin{array}{l}\text { Apabila muhșan, dihukum } \\
\text { rajam sampai mati; ghayr } \\
\text { muhșan dicambuk } 100 \text { kali. } \\
\text { (Berlaku bagi Muslim dan non- } \\
\text { Muslim) }\end{array}$ \\
\hline Pelecehan Seksual & $\begin{array}{l}45 \text { kali cambuk/ } 540 \\
\text { gram emas / } 45 \text { bulan } \\
\text { penjara }\end{array}$ & Tidak ada \\
\hline Pemerkosaan & $\begin{array}{l}125 \text { kali cambuk/ } 1250 \\
\text { gram emas/175 bulan }\end{array}$ & $\begin{array}{l}\text { Apabila muhșan, dirajam } \\
\text { hingga meninggal; apabila } \\
\text { ghayr muhsan, } 100 \text { kali } \\
\text { cambukan. }\end{array}$ \\
\hline Qadhaf & 80 kali cambuk & 80 kali cambuk \\
\hline Liwāt & $\begin{array}{l}100 \text { kali cambuk/ } 1000 \\
\text { gram emas } / 100 \text { bulan } \\
\text { penjara }\end{array}$ & $\begin{array}{l}\text { Disamakan dengan hukuman } \\
\text { zina (rajam atau } 100 \text { kali } \\
\text { cambuk) }\end{array}$ \\
\hline Musāhaqah & $\begin{array}{l}100 \text { kali cambuk/1000 } \\
\text { gram emas/ } 100 \text { bulan } \\
\text { penjara }\end{array}$ & $\begin{array}{l}\text { Denda } 40.000 \text { USD; dihukum } \\
\text { maksimal } 10 \text { tahun; dicambuk } \\
40 \text { kali; gabungan dari dua } \\
\text { hukuman. }\end{array}$ \\
\hline
\end{tabular}

Dari ketentuan jarimah dan hukuman yang ditetapkan di Aceh dan Brunei Darussalam tersebut dapat diteliti lebih lanjut bagaimana hukum Islam diterapkan dan bercampur dengan tatanan kehidupan umat Islam yang telah mapan. Dalam kasus Brunei, misalnya, jarimah dan hukuman yang ditetapkan hampir sepenuhnya mengikuti struktur dan tatanan hukum pidana Islam sebagaimana tercantum di dalam kitab-kitab fikih. Sebagaimana dalam khazanah fikih, hukum pidana Brunei Darussalam mengklasifikasikan tindak pidana menjadi dua bagian besar, yaitu tindak pidana ḥudūd (termasuk qiṣāṣ di dalamnya) dan tindak pidana umum yang tidak diatur di dalam al-Qur'an atau Sunnah (hukuman ta'zīr). Di sisi yang 
lain, hukuman-hukuman yang ditetapkan di dalam hukum pidana Brunei serupa dengan apa yang ditegaskan di dalam fikih Islam, seperti perzinaan muhșan (yang telah menikah) yang dihukum dengan rajam sampai mati, tindak pidana perampokan, qadhaf, dan pencurian.

Sementara hukum pidana di Aceh pada dasarnya lebih menyesuaikan dengan tatanan hukum dan masyarakat yang ada, di samping juga keberadaannya yang berada di bawah Negara Kesatuan Republik Indonesia. Dari segi hukuman dan tindak pidana, nampak adanya penyesuaian dan karakter yang berbeda antara hukum jināyāt di Aceh dan fikih. Hal yang paling nampak adalah tidak adanya pembedaan yang eksplisit antara tindak pidana yang termasuk dalam hudūd atau qișās dan tindak pidana ta'zīr. Di sisi yang lain, ada beberapa tindak pidana yang sebetulnya tidak termasuk di dalam ḥudūd atau ta'zìr namun juga dimasukkan ke dalam Qānūn jināyat Aceh, seperti perjudian, karena sejak awal praktik hukum pidana Islam di Aceh telah memasukkan tindak pidana ini di dalam Qānūn sebelumnya.

Di luar itu, terdapat pula perbedaan hukuman antara hukum pidana Aceh dan hukum pidana Islam yang ditegaskan di dalam kitab-kitab fikih, seperti khamar yang dihukum dengan hukuman cambuk sebanyak 40 kali, perzinaan yang dihukum dengan 100 kali cambukan. Kemudian, hukum pidana Aceh nampak berbeda dalam beberapa hal dengan fikih, yaitu ketika hukuman yang diberikan tidak sesuai dengan fikih, seperti dalam qadhaf yang disanksi dengan 40 kali cambukan di dalam al-Qur'an, sementara dalam Qānūn jināyat Aceh disanksi dengan 30 kali cambukan.

Qānūn jināyat Aceh juga tidak membedakan tindak pidana perzinaan, sebagaimana yang diatur di dalam al-Qur'an dan Sunnah dan Kanun Jenayat Brunei Darussalam. Qānūn Aceh hanya menegaskan satu bentuk hukuman, yaitu cambuk 100 kali bagi pelaku zina, baikyang terkategori sebagai zina muhșan ataupun ghayr muhșan.

Kedua sistem hukum pidana Islam di atas (Brunei dan Aceh) nampak adanya kesamaan dalam mengartikulasikan tindak pidana yang dipandang serupa dengan jarimah-jarimah yang telah ada, yaitu penetapan hukuman bagi tindak pidana pemerkosaan, liwāt atau homoseksual dan lesbi atau musāhaqah. Hanya saja, keduanya berbeda dalam hal hukuman yang diberikan kepada pelaku. Aceh menetapkan hukuman cambuk sebanyak 125 kali cambukan bagi pelaku pemerkosaan, sementara Kanun Jenayat Brunei menyamakan tindak pidana ini dengan perzinaan. Dalam hal liwāt, Aceh menetapkan 100 kali cambukan bagi pelaku,

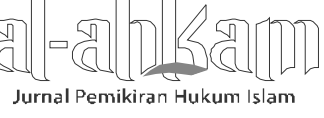


namun Brunei Darussalam menetapkan hukumannya sama dengan perzinaan. Sementara untuk lesbian, Aceh menetapkan sama dengan perzinaan, yaitu 100 kali cambukan, sementara Brunei menetapkan hukuman yang berbeda, yaitu dengan denda 40.000 USD, dihukum maksimal 10 tahun, dicambuk 40 kali atau gabungan dari dua hukuman yang terakhir.

Demikianlah perbedaan antara dua qānūn jināyāt yang ditetapkan di Aceh dan di Brunei Darussalam ini. Menurut hemat penulis, perbedaan itu tidak dapat dilepaskan dari konteks historis, sosiologis, dan politik di kedua wilayah ini. Keberadaan Aceh sebagai bagian dari Indonesia yang nota bene bukan negara agama yang meletakkan Islam sebagai dasar negara tentu memiliki perbedaan dengan Brunei Darussalam yang sejak awal menegaskan Islam sebagai agama resmi negara. Di luar itu, keberadaan sistem politik di antara keduanya juga berbeda, di mana Brunei Darussalam yang cenderung bercorak otoritarian di bawah kerajaan, sementara Aceh bercorak demokratis dengan multi partai.

\section{Kesimpulan}

Dibandingkan dengan aspek hukum yang lain, hukum pidana Islam (jināyah) merupakan cabang hukum Islam yang paling banyak digantikan penerapannya di masa kolonialisasi. Sampai saat ini ada banyak negara bekas kolonial yang masih menerapkan hukum pidana sisa penjajahan, setidaknya terjadi di Indonesia dan Brunei Darussalam (sebelum 2012) yang masing-masing dijajah oleh Belanda dan Inggris.

Dari penjelasan yang telah diuraikan di atas, pada dasarnya penerapan Syariat Islam sangat terkait erat dengan situasi dan kondisi sosio-politik sebuah komunitas. Sistem politik yang berbeda, misalnya, telah memberikan kontribusi pada perbedaan produk atau keluaran dari kebijakan yang dibuat oleh negara atau wilayah kekuasaan tertentu. Di sisi yang lain, kasus Brunei dan Aceh menunjukkan bahwa telah terjadi penyesuaian-penyesuaian hukum pidana Islam secara spesifik yang termaktub di dalam kitab-kitab fikih (sebagai gambaran dari al-Qur'an dan Sunnah) dengan kebutuhan-kebutuhan masyarakat itu sendiri. Hal ini kemudian menjadikan corak dan karakter hukum pidana Islam di dua wilayah ini berbeda pula; Brunei yang sangat ketat dan dekat dengan struktur hukum pidana Islam yang ditetapkan di dalam al-Qur'an, sunnah dan kitab-kitab fikih, sementara Qānūn jināyat Aceh lebih fleksibel dengan menyesuaikan dengan kebutuhan dan tuntutan masyarakat, termasuk pula keberadaannya yang tidak lepas dari Negara Kesatuan Republik Indonesia.[a]

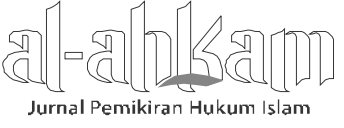




\section{DAFTAR PUSTAKA}

Aceh Reglement, Staatblad 1881 No. 82.

Awdah, Abdul Qādir, Al-Tashrī’ al-Jināî̀ al-Islāmī: Muqāranah bi al-Qānūn al-Waḍ̂̄, Beirut: Dār al-Kutub al-'Arabī, t.th., juz I.

Baderin, Mashood, Hukum Internasional Hak Asasi Manusia dan Hukum Islam. Jakarta: Komnas HAM, 2010, edisi terjemahan.

Iskandar, T, Aceh dalam Lintasan Sejarah: Suatu Tinjauan Kebudayaan. Prasaran pada Seminar Kebudayaan dalam rangka PKA II dan Dies Natalis XI Universitas Syiah Kuala, 21 - 25 Agustus 1972 di Banda Aceh

Kanun Hukuman Jenayat, Perintah di Bawah Perkara 83 (3) tahun 2013.

Lembaga Pembinaan Hukum Nasional (LPHN), Pengaruh Agama Islam terhadap Hukum Pidana. Hasil Penelitian dalam Rangka Kerjasama LPHN dan Fakultas Hukum dan Pengetahuan Masyarakat Universitas Syah Kuala Darussalam, Banda Aceh, Tahun 1972.

Mahdi, "Sistem Hukum Penegakan Qanun Jinayat di Aceh", dalam Media Syariah, Vol. XIII, No. 2, Juli - Desember 2011.

Mahmood, Taher, Personal Law in Islamic Countries. New Delhi: Academy of Law and Religion, 1987.

Mubarok, Acep Zoni Saeful, Hukum Keluarga Islam di Brunei Darussalam, dalam Atho' Mudzhar dan Khoiruddin Nasution, ed., Hukum Keluarga di Dunia Islam Modern: Studi Perbandingan dan Keberanjakan UU Modern dari Kitabkitab Fikih. Ciputat: Ciputat Press, 2003.

al-Naim, Abdullahi Ahmed, "Sharia in the Secular State: A Paradox of Sparation and Conflation", dalam Peri Bearman, dkk., ed., The Law Applied: Contextualizing the Islamic Sharia. London \& New York: IB Taurus, 2008.

al-Naim, Abdullahi Ahmed, Islam and the Secular State: Negotiating the Future of Shari'a. USA: Harvard University Press, 2008.

Qānūn jināyat Aceh Tahun 2014

Rahman, Ahmad Abdussalam Abdur, "Brunei Darussalam Negara Zikir: Hasrat Sultan Hasanah Bolkiah", Artikel dipresentasikan dalam Annual Conference Islamic Studies (ACIS) ke-10, Banjarmasin, 1 - 4 November 2010.

Rahman, Pengiran Dato Seri Setia Dr. Haji Mohammad ibn Pangiran Haji Abd., "Kemasukan Islam ke Brunei Darussalam dan Undang-undangnya", dalam

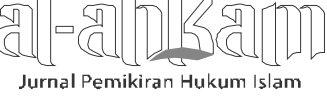


Dato Seri Setia Haji Metussin ibn Haji Baki, ed., Sejarah Penubuhan Mahkamah Syariah Negara Brunei Darussalam. Brunei Darussalam: Jabatan Kehakiman Negara Brunei Darussalam, 2005.

Salim, Arskal dan Azyumardi Azra, "Introduction: The State and Sharia in the Perspective of Indonesian Legal Politics", dalam Arskal Salim dan Azyumardi Azra, ed., Sharia and Politics in Modern Indonesia. Singapura: Institute of Southeast Asia Studies, 2003.

Suaedi, Ahmad, dkk., ed., Islam, Konstitusi, dan Hak Asasi Manusia. Jakarta: The Wahid Institute, 2009.

Wasti, Tahir, The Application of Islamic Criminal Law in Pakistan: Sharia in Practice, Leiden and Boston: Brill, 2009.

Zahrah, Abū, al-'Uqūbah: al-Jarīmah wa 'l-'Uqūbah fi 'l-Islām, Kairo: Dār al-Fikr al'Arabī, tth.

Zahrah, Abū, al-Jarīmah wa 'l-'Uqūbah fì l-Fiqh al-Islāmī, Kairo: Dār al-Fikr al-'Arabī, 1998.

Internet:

"Hukum Pidana Islam, DPR Aceh Sahkan Qanun Hukum Jinayat", Kompas, 27 September 2014, diakses dari http://regional.kompas.com/read/2014/ 09/27/11445201/Hukum Pidana Islam, DPR Aceh Sahkan Qanun Hukum Jinayat.

Naga, Marsen S., "Hukum Jinayat di Aceh", dalam Aceh Kita, 10 Desember 2009, diakses dari http://www.acehkita.com/2009/12/hukum-jinayah-di-aceh/ 